\author{
ЗОНА В. МРКАљ* \\ Универзитет у Београду \\ Филолошки факултет
}

\title{
МЕТОДИЧКИ ПРИСТУП РОМАНИМА ДОБРИЦЕ ЋОСИЋА У СРЕДЊОЈ ШКОЛИ
}

\begin{abstract}
У раду се разматра присуство дела Добрице Ћосића у настави српског језика и књижевности у периоду од првог објављивања одломка из дела Далеко је сунце у југословенским читанкама до данашњих дана, а акценат се ставља на Ћосићеве романе који се данас проучавају у средњој школи.

Увидом у начин на који се може приступити тумачењу романа Корени и одломцима из прве књиге романа Време смриии, приказује се улога различитих интеграционих чинилаца наставне интерпретације и разматра се однос тзв. спољашњег и унутрашњег (иманентног) приступа делу Добрице Ћосића, као и могуће корелације са другим наставним предметима и садржајима.
\end{abstract} школа.

Кључне речи: Добрица Ћосић, романи, настава књижевности, средња

Књижевно дело Добрице Ћосића заступљено је у скромном обиму у школским програмима, у односу на целокупно стваралаштво овог писца, мада представља изузетан материјал за остваривање многих циљева наставе српског језика и књижевности, и у образовном и у васпитном смислу. Далеко је суние је средином прошлог века био роман у домаћој лектири основаца; одломак из Деоба (сцена у цркви) обрађивао се у осмом разреду, а у средњој школи су се, као и данас, читали Корени и прва

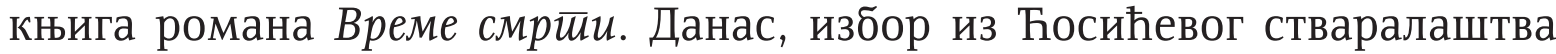
као обавезну лектиру читају само матуранти.

Разлоге за то можемо пронаћи на више страна: већина наставника сматра да богатство језика и стила Ћосићевог дела тешко могу прихватити и тумачити нешто млађи ученици; затим, познато је да је дело овог писца, као и он сам, увек имало одушевљене присталице, али и истинске противнике, а аутори школских програма најчешће полазе са становишта да политизоване теме у школи нису добродошле.

*mrkalj@ikomline.net 
Након Другог светског рата, Добрица Ћосић се појављује као стваралац који се смело суочава са проблематиком блиске историјске прошлости, актуелизујући у делу ратну тематику, однос човека према колективној идеологији новог доба и смисао борбе за егзистенцију. Тада настаје и роман Корени, који ће постати окосница читавог будућег ауторовог стваралаштва; наиме, писац је овим делом поставио темељ за све остале романе који прате судбине чланова више породица у кључним историјским дешавањима на тлу Србије и Балкана. Седамдесетих и осамдесетих година XX века настају најобимнија пишчева дела која развијају тематику Корена и Деоба, у којима се обимно, у широком приповедном оквиру историјских дешавања, прате појединачне судбине јунака који се истовремено суочавају са личним и друштвеним изазовима времена у коме живе. Почетак миленијума Ћосић је дочекао са романима у којима, надовезујући се на претходна дела стилски и естетски, приказује и тумачи суочавања са актуелним дешавањима из блиске историјске прошлости.

Ћосић је од првих романа развијао и усавршавао карактеристичан стилски израз. Поетика његовога приповедања заснована је на традицији реализма, али су његове приповедачке технике савремене, модерне, стваралачки утемељене и резултирају огромном естетском снагом. Стварни догађаји и личности интегришу се са светом фикционалних поетских простора, збивањима и ликовима, те аутор непрестано сучељава историјско и имагинарно, лично и колективно, актуелно и универзално. Ћосићева замисао о роману као уметничком сведочанству савремене историје земље актуелизује најболнија питања нације из њене савремене историје, почевши од албанске голготе (1915), преко сукоба са фашизмом, резолуцијом Информбироа, до распада земље и судбине државе и народа пред изазовима демократије. У фокусу таквог дела место су пронашле и историјске личности виђене очима приповедача, али и лик такозваног обичног човека који се у историјским искушењима увек суочава и са својим личним тегобама, запитаностима и недоумицама. Зато Ћосићева ангажованост има специфичан облик и карактер: она истовремено приказује, тумачи и вреднује историјско, досежући до разоткривања универзалних истина о савременом добу, о нацији, политици и, најзад, о човеку и животу.

Бављење делом нашег великог писца у средњошколској настави може започети мотивисањем ученика да прочитају одабрани одломак из читанке, који ће их подстаћи да прочитају цело дело:

У поетском простору поморавског села Прерово одвија се радња романа Корени. Породица сеоског моћника, богаташа и политичког предводника Аћима Катића суочена је са тешким изазовима: Ђорђе, 
Аћимов син који је остао на селу и оженио се Симком, не може да продужи породичну лозу наследником, а Вукашин, школован у Паризу, након седам година долази у породични дом пред велики хришћански празник са ставовима и одлукама које ће, у освит двадесетог века, заувек променити судбину читаве породице Катића.

Затим следи пројекат за истраживачко читање одломка из романа Корени, који је постављен и као функционално-мотивишући за читање дела у целини. У њему се акценат ставља на следеће значајне елементе тумачења: гледишта поводом дела и гледишта у делу; приповедачке технике; језичкостилска изражајна средства; наративно време; чулна имагинација; оживљене појединости; идејни слој текста; проблемска места, а на крају ученици добијају задатак да делу приступе уз помоћ плана тумачења који се може организовати према истраживачким смерницама. Како је припремање ученика за читање, доживљавање и тумачење дела (нарочито онога у обиму домаће лектире) изузетно значајна методичка радња, посебно ће се, с њом у вези, истаћи значај читања у поновљеном виду.

Мада Умберто Еко не сагледава читање у наставним околностима,

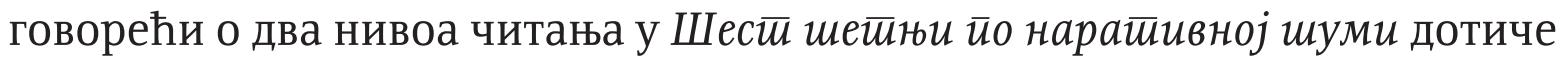
се појма иитиана у йоновљеном виgу. Прва стратегија читања је брзинска и њоме се удовољава читалачкој знатижељи. У другој стратегији читања читалац се појављује у улози мислиоца о садржајима дела, онога који активно промишља садржај, чита га више пута и настоји да проникне у његову тајну. Такав читалац је креативан до те мере да Еко његову активност изједначава са снагом и лепотама стваралачке ауторске делатности (уп. Еко 2003: 7). Овакво објашњење само додатно појачава потребу да се у наставу уводе истраживачки задаци.

\section{1. Корени - задаци за истраживачко читање}

У Коренима Добрице Ћосића ${ }^{1}$ оригиналним стилским изразом формирана је сложена поетика дела. Аутор је створио особен тип монолошког приповедања у коме су интегрисани водећи облици казивања (нарација, дијалог, монолог, унутрашњи монолог) и динамичко смењивање тачака гледишта приповедача и ликова из дела. Посредством приповедачевих гледишта и гледишта ликова поводом конкретних збивања, у дело се уносе различити временски планови, па је формиран, између осталог, утисак симултаности у приказивању прошлог и актуелног. Актуелна дешавања се доживљавају у светлу збивања која им претходе и условљавају их. Прошлост се успоставља на две равни, као ближа вре-

${ }^{1}$ Истраживања у овом раду остварена су према следећем издању (Ћосић 1997). Цитати текста из дела биће у наставку излагања означени одговарајућим бројем странице. 
мену нарације (деветнаести век) и као даља, која у дело уводи ликове Катићевих предака и посредством којих се доспева до генетичког и биолошког плана романа. Тематска сложеност дела је заснована на окосницама сусрета митског и традиционалног са нововековним, па се на примеру породице Катић приказују и расветљавају болни процеси који прате стасавање грађанске културе суочене са потребом да прошлост и ирационално усаглашава са практичном рационалношћу новог доба. 0 стваралачким интенцијама поводом језичког обликовања романа сведочио је и аутор, констатујући следеће: „Чинио сам напор да створим свој тип унутрашњег монолога, један свој метод тока свести, који, пре свега, мора да буде рационализован и самим тим комуникативан" (Булатовић 1954: 6). У лингвостилистичким анализама Корена запажено је да су поетичке окоснице романа и ауторске стваралачке интенције на непосредан начин исказане на језичкостилском плану дела. ${ }^{2}$

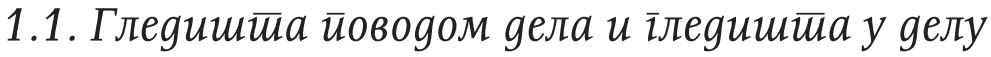

Представи која занимљива питања по твом мишљењу одломак ${ }^{3}$ из романа Корени покреће. Анализирај приповедачке технике и поступке у одломку. Запажај чије се тачке гледишта приказују. Издвој из одломка карактеристичне приповедачке облике: монолог, дијалог, нарацију и дескрипцију. Прати претапања која настају између унутрашњег монолога, монолога и доживљеног говора. Која се психолошка стања ликова њима дочаравају? Начини табелу карактеристичних исказа који илуструју ове појаве.

Ко је носилац фокализације на почетку одломка? На који начин се фокализација смењује током сцене Божићне вечере? Ко је фокализован на крају одломка? Тумачи каква се гледишта укрштањем, претапањем и смењивањем фокализатора формирају у тексту одломка. Прати и тумачи мотиве породичног раскола, братског сукоба и насилништва. Зашто долази до преплитања и сукобљавања породичног и интимног са политичким и идеолошким?

${ }^{2}$ Јелена Јовановић је стилском анализом Корена показала да се до целовитих језичкостилских гледишта на дело доспева у јединству прагматичких, граматичких и стилистичких анализа. Корисно је да гледишта саопштена у овом раду буду уважена приликом планирања методичког приступа Коренима како би се поуздано засновала целовита језичкостилска анализа дела (в. Јовановић 2009: 9-41).

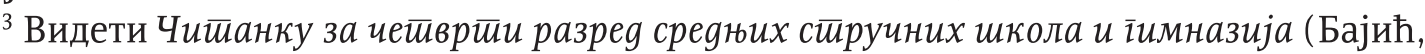
Мркаљ и Павловић 2016: 220-230). 


\section{2. Нарайивно време. Чулна имаїинација. Оживљене йојеgиностии}

Установи који се глаголски облици са временским значењем употребљавају током приповедања. Тумачи њихову улогу. Издвој сцене у којима су остварене ретроспекције и интроспекције. Објасни мотивацију сећања и преиспитивања ликова, посебно Вукашина.

Запажај појединости у свету дела: предмете; просторе пута, дворишта, куће; изглед пејзажа; гестове и поступке ликова.

Анализирај следеће исказе у одломку из романа:

- Оии му сииално беже йо снежном йоль и брежуљиима йореg Мораве.

- Уздахну са очима на снеі̄у у йазусима јасенова.

- Обешена изнаg кревет̄а йриђе му фот̄оі̄рафија из Париза

- [...] искашљава некакав мноїо нелаїоgан стирах.

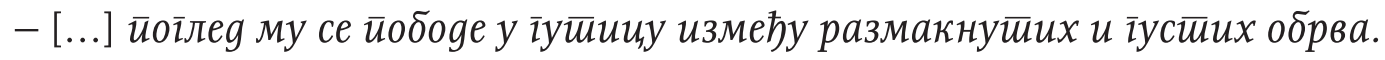

- По gуїом ћуйаґу кайље расииойљен восак.

- [...] осмех шмуінну у иуустиш браgе и бркова

- По њему звечи сув, изломљен лавеж.

- [...] каg је село заgављено снетіом, убијено йомриином шиио се измешала с облаиима

- [...] сасвим се оgсуйно зайлеgа у жеравииу која је исйала из фуруне и сйоро умирала на gасии, на којој су мнойе ирре юе за собом осиивиле ирне раниие (Бајић, Мркаљ и Павловић 2016: 231).

Раздвој исказе који дочаравају психолошка стања свести од оних којима се приказују предмети и појаве, као детаљи у свету дела. Откриј како се материјализују апстрактна душевна стања свести ликова. Посредством којих стилских изражајних средстава оживљавају детаљи из дела у твојој читалачкој свести?

\section{3. Он не долази кући као некаgа}

Због чега се приказана Вукашинова посета кући разликује од свих некадашњих долазака у родни дом? Каква сећања у њему побуђује ова посета? Која га питања заокупљају? Откривај које животне ставове преиспитује и са каквим се недоумицама интензивно бори. Зашто Вукашин предосећа да се налази на прагу новог живота? Каква га је промена отуђила од породице? Због чега Вукашин мора да се одрекне порекла да би формирао своју породицу? Запази како на његову посету реагује Симка. Проучи њену осећајност. Како Вукашинов долазак доживљавају Ђорђе и, посебно, Аћим? 


\section{4. Наg нейојеgеном вечером}

На који начин се приповедачки умешно појачава читалачка пажња ћутањем и мучном тишином за Божићном софром у кући Катића? Образложи које недоумице поводом Вукашиновог доласка муче Ђорђа, а које Аћима. Како Аћим најпре реагује на вест о Вукашиновој одлуци да се ожени? Шта га спречава да се лепој вести обрадује? Зашто је срећу и будућност здравог односа са сином осујетио политичком задојеношћу и нетрпељивошћу?

Запази чиме је Вукашин подстакнут да искаже своје идолошке ставове. Објасни због чега се политика и борба за власт готово неизоставно уплићу у личан и приватан живот. Зашто је актуелну друштвену слику описао речима „хајдучко позориште”?

Којим речима, ставовима и поступцима Аћим потврђује да га је страст за влашћу запосела до те мере да му је моћ важнија од среће сина? Процени шта га спречава да разуме Вукашина и толерантно прихвати његове ставове и животне одлуке. У Аћимовим гледиштима откривај и тумачи универзалне истине о снази власти и њеној моћи да заслепи племенитост и хуманост појединаца.

Како се Ђорђе понаша и о чему размишља током Вукашиновог сукоба са оцем? Шта је Ђорђу примарно у животу? Опиши његове реакције поводом Вукашинове жеље да поделе имање. По чему се види да се његова реч не поштује?

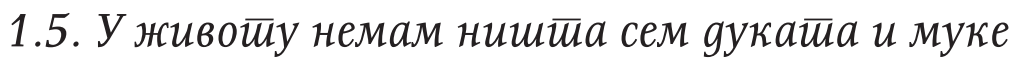

Зашто је Ђорђе незадовољан чак и онда када се Аћим одрекао Вукашина? Чиме је испровоциран његов бес? До какве сурове животне спознаје он доспева? Зашто му дукати не обезбеђују срећу у животу? На који начин испољава незадовољство? Због чега Симка беспоговорно трпи његово насилништво? Шта је у ударцима насилног супруга препознала и схватила, што заокупљена свакодневицом и газдинским пословима није успевала да увиди? О каквом положају жене у друштву сведочи Симкин лик? Чиме је условљен њен социјални опстанак?

\section{6. Прича с оквиром}

Проучи уметничку улогу приче с оквиром у роману Корени. Представи и објасни њене пролошке и епилошке садржаје.

Због чега је баш слуга Никола наратор у причи с оквиром? Које су побуде његовог приповедања? Издвој исказе којима ћеш потврдити његову тежњу ка уверљивости и заснованости причања. У којим се искази- 
ма уочава његова дирљива наклоност према Симки? Чиме је такав став подстакнут? Какву улогу у Николином монологу имају жеља да победи ограниченост живота, одбаченост и изгубљено поверење у људе? Какво важно и трајно сведочанство Никола оставља? Протумачи због чега себе именује летиойисием. Анализирај изглед који добија романескна прича о Катићима посматрана кроз визуру Николиног приповедања.

Којим облицима казивања и стваралачким поступцима је остварено Николино приповедање? Представи исказе у којима он самога себе представља и описује. Која животна гледишта непосредно саопштава? Анализирај их у контексту дешавања која се приказују у роману и тако откривај њихова значења. Зашто казивање упућује једном наратеру, Адаму? Због чега Адама доживљава као јединог наследника Катића? Своја гледишта поткрепљуј конкретним садржајима из дела.

\section{2. Поступност у наставном тумачењу романа Корени Добрице Ћосића}

\section{1. Језик романа и естетеиски донивљаји}

Уважавањем пишчеве методологије и стручних лингвостилистичких гледишта у методичком приступу роману Корени омогућено је целовито проучавање дела на темељу анализе језичкостилских поступака. За њега би се ученици припремали помоћу одговарајућих задатака.

- Читајте Ћосићев роман Корени. - Запажајте карактеристике језика и стила у делу. - Проучавајте естетску улогу и поетску снагу језика. - Припремите се да о лепоти и оригиналности језика у роману свестрано говорите на часу. - Запажајте и бележите исказе који су привукли вашу читалачку пажњу. - Објасните зашто сте управо њих издвојили. - Којим стилским средствима се у њима досеже поетска моћ језика? - Каква гледишта на дело, садржај и ликове изабрани искази доносе? - Протумачите их у контексту романа.

Језик Корена одликују сликовитост, оригиналан приступ обликовању исказа и специфична лексика, па ће његова привлачна моћ бити у основи читалачких активности и доживљаја ученика поводом романа. Они ће бити изненађени сложеношћу приповедања у делу и запазиће да се романескно многогласје сажима у јединствен приповедачки глас којим се приказују бурни догађаји из живота породице Катић. Сложеност приповедања и карактеристично стилско обликовање језика подстицаће свесну пажњу ученика, као и интересовање да читањем доспеју до одговора на питања која се покрећу у фабули. Ученици ће за- 
кључивати да је језик дела интересантан, оригиналан и привлачан, те да мноштвом стилскоизражајних поступака којима је обликован подстиче машту, многобројне читалачке асоцијације и снажне естетске утиске. Сигурно је да ће многи искази из романа привући читалачку пажњу ученика, те ће их они током читања бележити и спремно о њима говорити на часу. У експресивним реченицама аутор је дочаравао свет дела, поетски простор и време ${ }^{4}$, ликове, њихове речи, поступке и духовна стања ${ }^{5}$. Поједини искази формално и садржински одговарају природи мисаоних сентенци у којима се саопштавају важна животна гледишта, разрешавају моралне недоумице ${ }^{6}$ или покрећу политичка гледишта ${ }^{7}$ која су универзалне природе и стога инспиративна за проблемско разматрање. Ученици су мотивисани да издвојене исказе тумаче и у контексту романа, па ће се таквом активношћу формирати повољне околности за тумачење идеја, порука и највишег смисла дела.

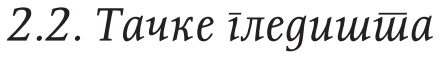

- Проучите тачке гледишта приповедача и ликова у роману са становишта језика и стила. - Којим се облицима казивања тачке гледишта формирају и приказују? Како су на језичком плану оне раздвојене и

4 „Лаке и хитре светлости и сенке налећу једне на друге, измичу и опет налећу гонећи се по изрибаном дашчаном поду и резбаријама храстове таванице. Сенке нечујно играју по дрвеним решеткама у прозорима искићеним грожђем" (Ћосић 1997: 67).

„Почађавела кафана гура се у врелу маглу уморног пијанства, боли га у стомаку, стеже једњак, и њише у глави, глава се њише од тавана до пода, ваља се по нагнутом келнерају, пече се на фуруни обешеној о лампу, столови - изврнуте бубашвабе, копрцају се са шест, осам сувих ножица и хоће да уштину угарке што урлају, урлају" (Исто, 116).

"Скупштинска дворана зањихала се као претоварена скела" (Исто, 301).

„Из последње куће нариче лампа” (Исто, 307).

5 „Уживао је, гледајући је кроз прозор кад висока, боката а витка, лако као усправни вал заплови двориштем, испуни га свег, па су кућа и зграде и јасенови мали, играчке за децу; одједном су сва врата затиснута њоме, а руке немирне, као да расад саде" (Исто, 37).

„Један другоме изубадаше очи шиљатим, густим погледима” (Исто, 83).

„Њен уморан и јецав уздах дуго је пузио по каменим ребрима цркве” (Исто, 134).

„У ћутању, њена суза исече се на ножу” (Исто, 223).

${ }^{6}$ „А човек умире једино кад мора и кад неће” (Исто, 5).

„Наша су гробља млада” (Исто, 9).

„Веруј ми, у злу су сви људи зли” (Исто, 10).

„Кукавице гуслају, а људи гину” (Исто, 182).

„Човек хоће бар онолико колико си бубама дао: да се множи и пати толико да никад не може да угине" (Исто, 347).

7 „Рат с Турцима пренет у рат за власт, у политику. А политика на трпезу и у постељу" (Исто, 55).

„Живот у Србији је старо гробље... Ништа велико у њему не може да израсте. Ко год од живота нешто више тражи - рубе му главу" (Исто, 73). 
препознатљиве? - Издвојте и протумачите наративне деонице у којима се поводом једног дешавања или догађаја приказују тачке гледишта различитих ликова. - Каква је улога мисаоне асоцијативности у разграничавању, али и повезивању тачака гледишта?

- Запажајте како се посредством тачака гледишта уводе нови мотиви и гранају тематски планови романа. - На који начин се сазнаје о догађајима који непосредно претходе дешавањима која се приказују као актуелна? - Којим се језичким средствима у дело уносе и дочаравају митска времена из прошлости Катићевих?

Приповедачка тачка гледишта обухвата тачке гледишта свих других водећих ликова Корена. Свет романа почива на множини свести које приповедачки глас поставља у узајамно садејство. Глас приповедача стапа се са гласовима ликова, а овај поступак означен је на формалном плану одсуством графичких обележја којима би се истицали дијалози или облици монолошког казивања. Наводници су употребљени само у деоницама нарације који приказују дијалоге и монологе унутар ретроспекција. Промену тачке гледишта и фокализацију прати одговарајућа лексика у којој се испољавају карактерна, социјална, образовна и психолошка својства ликова. Приповедачко гледиште сажима, повезује и регулише динамику и интензитет гледишта ликова, а остварено је тако да се поводом кључних догађаја успоставља више различитих гледишта. Тако је, на пример, сцена Вукашинове свађе са Аћимом приказана са тачке гледишта три лика: Вукашина, његовог брата Ђорђа и Симке. Унутар појединачних тачака гледишта шире се нови садржински планови романа и проширује његов временски приповедни оквир. Ликови се у ретроспекцијама и реминисценцијама враћају у прошлост, најчешће асоцијативно подстакнути дешавањима чији су учесници и које снажно проживљавају. У садржај дела овакав поступак уводи нове мотиве и проширује тематику: Вукашиново сећање на одрастање, одлазак у Париз, школовање и повратак у Србију, Симкино доживљајно враћање у прошлост брачног живота са Ђорђем и живота у породици Катић или, још дубље, њено сећање на породицу из које је потекла и мучан сиротињски живот пре удаје. Овим стваралачким поступком у роман је унет митски слој приче о Катићима. Он се успоставља кроз Аћимово призивање сећања (унутрашњи монолог) у коме се реконструише сцена Вукашиновог поласка на школовање у иностранству. Том приликом отац је сину испричао генеалогију породице како би га охрабрио да на студијама истраје и постане први Катић који има универзитетско образовање. На језичком плану прошла и актуелна дешавања се раздвајају одговарајућим глаголским облицима за исказивање прошлости. 


\section{3. Дијалошко-монолошки сйлейови}

- Изучавајте преплетај дијалошког и монолошког у приповедању. - У којим сценама он снажно долази до изражаја? - Зашто баш у њима? - Шта ликови говоре, а о чему мисле? - Какви доживљаји прате њихов говор и размишљања? - Изучавајте структуру реченица којима се постиже уверљиво сликање вишестраних гледишта. - Пратите и тумачите на одговарајућим примерима којим се језичким средствима формира утисак о говорној интонацији у писаном тексту.

Читалачка пажња посебно је побуђена специфичним дијалошко-монолошким сплетовима у роману. Они се појављују у сценама сукоба ликова и напетости која влада у њиховим сложеним међуодносима: расправе Вукашина са Аћимом и Ђорђем, сукоб Симке и Ђорђа, сусрет Толе Дачића и Симке. У актуелни дијалог се уплићу унутрашњи монолози ликова којима се слика сложен мисаони сплет, а истиче склоп емотивних реакција које приказана дешавања у ликовима побуђују. Понекад су упливи монолошког кратки и сажети, приказани као мисаоне и емоционалне реакције на понашања, речи и ставове других ликова, а што је остварено кратким и елиптичним исказима. Монолошко казивање доживљава се као водеће у роману, а оно је доследно обликовано интонацијом говорног језика, тако што је приказано као обраћање лика одсутном наратеру или наратерима, односно самима себи. Најчешће се у монолошким деоницама ликова који учествују у дијалозима продубљују сећања на прошло које утиче на ток и исход сукоба који је између ликова успостављен у конкретној сцени. Читаоцима је на тај начин омогућено да уоче раскораке између онога што ликови говоре и тога што мисле, да се упознају са природом емоција и доживљаја који их обузимају у дијалозима и да сагледају утицај прошлости на ставове ликова, њихова гледишта, речи које изговарају у дијалозима, на понашање и одлуке које доносе. Откриће се да су моралне недоумице и кључна гледишта ликова Катићевих дубоко укорењени у прошлости која сеже све до митских времена, из доба када је породица конституисана.

У роману Корени Добрице Ћосића у причи с оквиром се утемељује модерни монолошко-асоцијативни композициони тип романа. Свака од четири приповедне целине фокализује битан догађај из живота Катићевих, а потом се представљају монолошке и асоцијативне реакције ликова поводом онога што проживљавају подстакнути кључним дешавањима. Сведок њихових егзистенција је слуга Никола, чији лик је стожеран у причи с оквиром. Зато се њеном проучавању у композицији романа посвећује посебна пажња. 
Експресивна снага језика у појединим романима чврсто је повезана са свим водећим структурним елементима, те се њеним тумачењем разоткрива највиши смисао дела.

Анализом граматичких облика и изражајних средстава језика у роману ученици ће помоћу одговарајућих примера уочавати специфичност поетског израза у делу. Запазиће да је у роману доминирајуће глаголско време аорист, којим се збивања која су актуелна, а посебно она која су далека, приказују као блиска времену нарације. Употребом аориста успоставља се експресивна снага приповедања, али се истовремено сугерише да је ближа или даља прошлост снажно жива у ликовима, да су они њоме заокупљени можда и више но што су свесни јер им прошлост подједнако снажно условљава и доживљаје и гледишта на судбоносна животна збивања.

Дескриптивне деонице текста Корена су кратке. Оне сликају поетски простор, изглед, односно понашања, гестове и мимику ликова фокусиране у конкретном времену и најчешће пројектоване из свести неког од ликова. У описивању доминира именски предикат, који је карактеристичан за кратке реченице, и то оне којима ликови квалификују неку појаву, предочавају сопствена гледишта или ставове саучесницима у дијалозима. Пејзаж и предметности најчешће су персонификовани или дочарани сликовитим и оригиналним поређењима. Дескрипцијом се сликају унутрашња стања ликова, па се простор, свет и други људи предочавају као одрази махом узнемирене свести која се бори са конкретним егзистенцијалним тегобама. Стање узнемирености и великог емоционалног набоја дочарава се и понављањем лексичких јединица. Успостављени репетитивни низови карактеристични су у дијалозима ликова чија се гледишта оштро сучељавају, али и у унутрашњим монолозима који сведоче о психолошкој пренапрегнутости лика (какав је, рецимо, Симкин монолог на исповести). Понекад су лексичке репетиције пропраћене испрекиданим говором који је истакнут употребом тротачке.

Већ приликом саопштавања доживљаја ученици су говорили о експресивним исказима који су на њих оставили утиске. У посебној наставној ситуацији радну пажњу ученика треба усмерити ка исказима који имају ритам и звук карактеристичан за епски десетеращㅇ. Придружени

${ }^{8}$ Јелена Јовановић (2009: 38-39) истакла је ритмичку организацију исказа као једну од основних стилских карактеристика Корена. Запазила је такође да у роману нема странице на којој се не појављује бар један исказ у форми епског десетерца. Она је навела, између осталих, следеће илустративне примере: „Аћим Катић неће вас издати”; „Зар на вашу браћу и очеве?”; „Еј да сам те некад млађи срео”; „Јесам слуга, а радим шта хоћу". Контекстуализовано проучени, ови искази указаће ученицима на дискурс сукоба између прошлих, турских времена и дух традиције у свести ликова, посебно у ликовима Аћима, Николе и Толе. 
и здружено проучени са сентенциозним реченицама, ови ће искази учествовати у аналитичкосинтетичком приступу проучавању водећих значења у роману.

До формирања стваралачких гледишта на дело са становишта језика и стила доспева се усаглашено са динамиком интерпретације других обједињујућих чинилаца. Најбољи интерпретативни резултати постижу се повезивањем методичких подстицаја који су намењени проучавању језика и стила са тумачењем структурних чинилаца у којима је језичкостилско обликовање истакнуто заступљено.

Дело Добрице Ћосића омогућава савладавање многих, за наставу нових књижевнотеоријских појмова, који се, пре свега, могу везати за наратолошки приступ тексту. Тако ученици сазнају за појам фокализаu, uјe, која означава перспективу из које су перципирани догађаји у приповедном делу, затим, за gоживљени іовор, као вид приповедног дискурса помоћу којег се у наративном тексту предочавају мисли или говор јунака. Исказан је у трећем граматичком лицу, али уз одсуство уобичајених индикатора који указују на то да је уведен говор јунака. Пример:

1. директни говор: „Желим да нестанем!”

2. индиректни говор: Рекао је да жели да нестане.

3. доживљени говор: „Жели да нестане.”

Затим се открива појам инйросиекиије и сазнаје се да се она јавља кроз тему усредсређености писца на сопствени духовни живот (као у дневнику или аутобиографији), кроз књижевни поступак који оставља утисак да се „изнутра” посматрају мисли и осећања јунака. Интроспекција се остварује различитим књижевним техникама, као што су: солилоквиј, унутрашњи монолог, ток свести, доживљени говор, драмски монолог и сл.

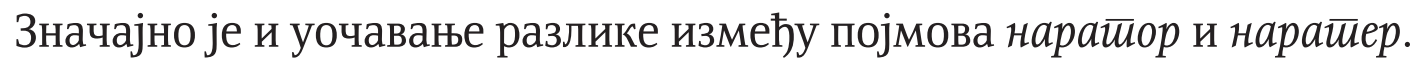

\section{3. Време смрти}

Стваралачко обликовање романа веома често подразумева $y н y \bar{u} p a-$ шње локализовање. Аутори су просторне и временске одреднице збивања уврстили у приповедни садржај како би успешно дочарали атмосферу и својства света дела, чијим се расветљавањем доспева до проучавања условности у приказу ликова, њихових судбина и егзистенције. Зато је потребно подстицати ученике да уметничку локализацију у делу запажају и истраживачки проучавају, односно да анализирају стваралачке поступке којима је остварена. Ученици ће се мотивисати да проучавају унутрашњу локализацију у роману Време смриии Добрице Ћосића. 


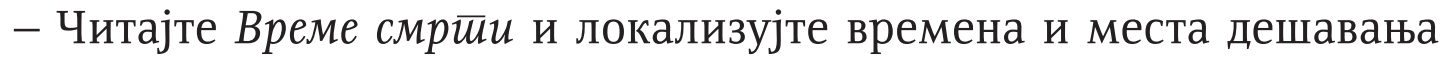
развијене радње романа. - Установите стилскојезичке поступке којима је приказано време уочи и током Првог светског рата. - Испитајте зашто су Прерово, Ваљево, Мионица, Сувобор и Албанија главне просторне одреднице у роману. - Повежите просторе збивања у делу са подацима о Првом светском рату на тлу Србије. - Тумачите на који начин се уметничка локализација у роману остварује као битно извориште сложених естетских значења у делу.

Ученици ће установити да радња Времена смрйи обухвата временски период уочи и за време Првог светског рата. Пошто су им историјски подаци о овом временском периоду познати, а и наставник их подстиче да их се благовремено подсете, ученици ће у делу запажати условности између историјских збивања и садржаја романа. Они ће разлучити више простора у делу и закључиће да се село Прерово приказује као карактеристични сеоски амбијент Србије с почетка двадесетога века. У том простору и стиже вест о избијању рата, па се реакцијама ликова људи из села, а посебно Катића и Дачића, на уверљив начин приказују доживљаји породица чији су мушки чланови мобилисани. Прототипски локалитети Ваљева, Мионице и Сувобора унети су и у делу приказани као естетски простори у којима су центри бурних дешавања током ратних сукоба. У Ваљеву је била смештена чувена ратна болница, у Мионици је заседао ратни савет, а на Сувобору се одиграла једна од кључних битака с почетка рата. Ученици ће запазити и протумачити да је овим просторима у роману дато истакнуто место посредством детаљније дескрипције. За сваки од ових простора везује се и по један од ликова романа: у Ваљеву је Милена Катић, у Мионицу доспева њен отац Вукашин, а на Сувобору је Адам. Сви ови и други ликови романа повезују се затим хронотопом пута на који крећу у избеглиштво преко Албаније. Национални егзодус уједињује ликове романа хронотопом пута на коме се они или не сусрећу непосредно или не препознају, а што, између осталог, сугерише суров утицај трагичних историјских збивања на раздвојеност најближих, који су доведени у ситуацију да ратне агоније проживљавају усамљено и болно.

Тумачење значајних сцена и појединости из романа организује се и планира за обраду посредством ужег локализовања. Како би се ученици током обраде дела усмерили ка одговарајућим сценама, потребно је остварити уже локализовање и у центар истраживачке пажње и интерпретативног рада довести истакнуте предметности тумачења. Током припремања ученици се мотивишу да функционалне наративне садржаје запазе и тумаче их у контексту дела. 
За ученике ће сигурно многе сцене из романа у којима се појављује лик Живојина Мишића бити интересантне, а посебно оне када се непосредно доводи у везу са фиктивним ликовима, као, на пример, приликом сусрета са Толом Дачићем. Ову сцену ученици ће доживети као сусрет чињеничног и фиктивног, који Мишићев лик приближава свету дела. Уверљивост у његовом приказивању заснована је на уважавању чињеничне грађе, али је посебно снажно истакнута духовна и психолошка страна лика. На пример, у сцени доношења судбоносних одлука читаоци су у повлашћеном положају да прате и доживљавају осећања и мисли Живојина Мишића кад дође у родни Струганик и снажан лиризам присутан у асоцијативним сећањима на породицу, посебно на ликове мајке и деде. Сетиће се како му је мајка тепала и како је деда игром са штапом пресудио који ће од браће поћи на школе, а ко остати на домаћинству. Дедина наклоност истакнута је према малом дечаку, нежном и крхком, који није био за тежачки и мукотрпан сеоски рад, па га деда подстиче да победи у игри, отпутује у официрску школу и тако се спасе тежачког живота. Мишић је у интроспекцијама и ретроспекцијама у роману приказан као мудар и емотиван човек који испуњен недоумицама страхује и стрепи над последицама својих одлука, али их не манифестује, како би пред народом и војском наступио поуздано и одважно. Ученици ће у тумачењу доспевати и до универзалних спознаја о томе да се судбоносне колективне одлуке не доносе лако ни напречац, да су тешке - посебно мудрим и свесним руководиоцима. Страхови од последица одлучивања и сумње у сопствене ставове својствене су и личностима чије пресуде историја описује објективним и безличним тоном. Упознаваће се и поетика романескне фикционализације, у којој се тежи приказу садржаја недоступних у стварности и непосредном искуству.

Као уважен стваралац, Добрица Ћосић је често био у прилици да непосредним ангажовањем учествује у актуелним политичким дешавањима. Увек је декларисао своје политичке ставове и идеје, прихватао или одбацивао поједине политичке смернице. Савремена критика, па и шира читалачка јавност, Ћосићево дело је често посматрала и доживљавала кроз његов политички ангажман, у чему је било и одушевљеног величања и огорченог одбацивања. Међутим, пишчев јавни ангажман потврдио је, као много пута досад у историји уметности и књижевности, да су идеологија и политика често заокупљене промовисањем гледишта која се олако релативизују, док се трајни хуманизам и вредности показују у пуном светлу управо у човековим стваралачким активностима и делима. Наставна тумачења одабраних Ћосићевих романа управо ову мисао истичу у први план. 


\section{ИЗВОРИ И ЛИТЕРАТУРА}

Булатовић, Миодраг. „Један тренутак са Добрицом Ћосићем”. Кюижевне новине, бр. 6, (1954): 6. Шт.

Бајић, Љиљана, Зона Мркаљ и Миодраг Павловић. Чийанка, уибеник за чейврй разреg іимназија и среgюих сйручних школа. Београд: Klett, 2016. Шт.

Eko, Umberto. Šest šetnji po narativnoj šumi. Preveo Lazar Macura. Beograd: Narodna knjiga, 2003. Št.

Јовановић, Јелена. Писии и стиил. Београд: Друштво за српски језик и књижевност Србије, 2009. Шт.

Ћосић, Добрица. Корени. Београд: Београдски издавачко-графички завод, 1997. Шт.

Zona V. Mrkalj

\section{METHODOLOGICAL APPROACH TO THE NOVELS OF DOBRICA ĆOSIĆ IN THE SECONDARY SCHOOL}

\section{Summary}

The paper discusses the presence of Cosic's work in teaching Serbian language and literature in the period from the first publication of an excerpt from work Far is the Sun in the Yugoslav reading books up to the present day, and emphasis is placed on Cosic's novels that are now being studied in high school.

The insight into the way in which the Koreni novel can be accessed and the passages from the first book of the novel The Time of Death, shows the role of various integration factors of teaching interpretation, and the relation of the so-called external and internal (immanent) approach to the work of Dobrica Ćosić, as well as possible correlations with other teaching subjects and contents. 